\title{
HISTORICAL EVOLUTION OF FEDERAL FINANCES IN INDIA
}

\author{
by K. Gopa Kumar*
}

*Gulati Institute of Finance and Taxation Kaimanam, Pappanamcode (PO), Thiruvananthapuram, Kerala, India

Email: drkgopakumar@gmail.com

\begin{abstract}
The paper confirms that the provisions of fiscal federalism laid out in the Indian Constitution are connected to the legacy of the British rule in India. Applying historical analysis the author divides the period from the starting of British imperial administration in India to the enactment of Indian Constitution into five different phases on the basis of the evolution of Centre-Province financial relations. The principles of fiscal federalism in India gradually evolved from highly centralized fiscal governance during the initial period of the British rule until being manifested in the Constitution. Various parliamentary enactments, executive directions, committees and commissions as well as individual intervention contributed to this transformation. The paper further lays out the unique features of the Indian Constitution such as mutually exclusive tax domains and various mechanisms addressing fiscal imbalances due to the Government of India Act of 1935 enacted by the British Parliament. It concludes that while British authorities designed the system of fiscal administration in India after their preferences, the makers of the Indian Constitution preferred to retain the same provisions with minor variations in the Constitution of independent India.
\end{abstract}

Keywords: fiscal federalism, India, history

Gopa Kumar, K. 2012, "Historical Evolution of Federal Finances in India", Federal Governance", vol. 9 no. 2, pp. 27-44. 


\section{About Federal Governance}

Federal Governance is an online graduate journal on theory and politics of federalism and multi-level governance. Its mandate is to engage the global federalism community and reach out to outstanding graduate students interested in federalism and multi-level governance. By providing a platform for graduate students to have early success in their careers, Federal Governance seeks to promote and sustain interest in federalism and multi-level governance research among graduate students. Allied with the Forum of Federations and founding partner, Institute of Intergovernmental Relations at Queen's University; Federal Governance aims to contribute to a global dialogue on federalism.

Co Chairs, Advisory Committee: Rupak Chattopadhyay and Christian Leuprecht

Publisher:

Forum of Federations

(Rupak Chattopadhyay and Rod Macdonell)

Managing Editor:

Dominic Heinz

Associate Editors:

Maria Bertel, Joshua Cerovski, Carey Doberstein, EvaMaria Maggi, Sean Mueller, Eyene Okpanachi, Samir Sharma and Victoria Tait

\section{Terms of Use}

Your use of this Federal Governance article indicates your acceptance of Federal Governance's Terms and Conditions of Use, available at www.federalgovernance.ca/terms. Federal Governance's Terms and Conditions of Use provides that you may use Federal Governance content only for personal, academic and non-commercial use. Each copy of any part of this Federal Governance article must contain the same copyright notice that appears on the screen or printed page of such transmission. All errors are those of the author(s). 


\section{Introduction}

The provisions of fiscal federalism under Indian Constitution are not, as in the cases of many other provisions, result of any indigenous thought process. They are, to a great extent, indebted to the previous constitutional forms that have been developed in the country during British rule. The British Government assumed direct sovereignty over the territories of the East India Company in India in 1858 and ruled the country for about a century. During this long period of imperial rule, principles of fiscal federalism were developed through parliamentary enactments and executive directions.

Based on the major developments from the year 1858, when the British Crown assumed direct sovereignty over the Indian territory, to the year 1950, when India became a Sovereign Republic, the evolution of fiscal federalism in India can be broadly divided into five phases: (1) Conceptualizing decentralised finance: 1858 to 1871 (2) Informal decentralization of finances: 1871 to 1919 (3) Formal decentralization of finances: 1919 to 1935 (4) Decentralization to federal finances: 1935 to 1947; and (5) Starting of Constitutional fiscal federalism: 1947 to 1950.

This paper attempts to highlight the important schemes, enactments, and regulations etc., during these periods which have made significant contributions in the field of Centre-state financial relations in India.

\section{Conceptualising decentralised finance: 1858 to 1871}

The period from 1858 to 1871 did not make any significant contribution towards decentralising the financial administration in India. In the initial years, the principle of rigid centralisation got prominence and was implemented rigorously. When the Crown took over the administration, the status of financial administration was alarming. Nothing like an annual budget existed and it hardly followed any standardized system of accounting.

Mr. James Wilson was made the first financial member of the Governor General's Council. Under the system then introduced, the central Government retained the entire control of finance and made grants of money at its discretion to meet the demands of the Local Governments. The Local Governments were collecting the greater part of the revenue merely as the agents of the central government. The 
result was that the former was left with no direct interest in the result of collection since the whole amount went to the common fund, managed by the central authority, which controlled the smallest details of every branch of the expenditure (Kale 1917). ${ }^{1}$ Samuel Laing, who succeeded James Wilson, was the first person to propose to grant some financial powers, including power to taxation, to the provinces. His proposal was that the provincial governments should be vested with the power to raise money by taxation for financing public works, as the Imperial revenues were inadequate.

Finance Minister William Massey (1866-68) was an ardent supporter of decentralisation of finance. He was of the opinion that "in the vast and various provinces which are united under the dominion of the Crown throughout the continent of India, there are many sources of revenue which might be made available for local purposes, but which could not be used for imperial objects without giving rise to just complaints of partial exaction or even breach of faith"(Government of India 1867).His principles were embodied in a scheme of decentralisation of finance formulated by Col. Strachey. According to Strachey scheme, roads, jails, education, and medical services should be transferred to the provinces. It was further suggested that one-sixteenth of the land revenue and one-fourth of the proceeds of licence tax should be allotted to the provinces. The scheme recommended that the Provinces should be empowered to augment their revenue by imposing additional taxes and cesses on the existing taxes (Government of India 1867).

Lord Mayo who became the Governor-General in 1870 started implementing the recommendations of Laing and Strachey. For enhancing the fiscal powers of the Provinces and making them more responsible in the fields of financial administration, Lord Mayo issued a resolution on December 14, 1870.

The first phase of the financial decentralisation ended with the steps taken by Lord Mayo. During this phase nothing significant took place for decentralising the financial administration except having some serious considerations regarding such a system. The schemes and plans during this period were mainly oriented to inculcate

\footnotetext{
${ }^{1}$ He points out that this position of the subordinate Governments was most galling to the Central Government and the new system that aimed to set right the economy, in fact led to extravagance. The Provincial Governments were tempted to ask for more than they expected to get and expended every pie that they received when they could have managed with less.
} 
a sense of financial responsibility in the Provincial Governments and to reduce the financial burden of the Central Government.

\section{Informal Decentralisation of finances: 1871 to 1991}

The period from 1871 to 1919 witnessed a gradual process of progressive devolution of financial authority from the Central government to the Provincial governments. In 1871 Lord Mayo took up the issue of decentralisation of finance as part of a plan for restoring equilibrium to the Imperial finances, which were in a state of chronic deficit. Under the Mayo Scheme, a Provincial Financial Settlement was laid down in which the provinces were to get more financial powers.

\section{a. Provincial Financial Settlements}

Under the Provincial Financial Settlements, certain heads of expenditures were assigned to the Provinces. Receipts under the corresponding heads were assigned to the respective provinces for meeting expenditure under those heads. However, as the receipts under these heads were not commensurate with the expenditure, it was decided to continue with the existing system of fixed grants from the Central revenues. $^{2}$

The Provincial Financial Settlements did not help to improve the provincial economy. On the other hand it has resulted in increasing the horizontal imbalances among the provinces. The Provinces were empowered to supplement their revenue by additional taxation, which under the existing arrangements could only mean increased burden on the poor (Jather\& Beri 1932). However, the Mayo Scheme had put the process of decentralization of finances into motion, which could not be reversed.

\section{b. Provincial Financial Settlement widened}

2 Under the Provincial Financial Settlements, the Provinces were given a total grant of Rs. 4688711/- in lump sum. This amount was distributed as between the several provinces by the Government of India, on the basis of the requirements of each province, as shown by the accounts of the Government of India. 
In 1877, some steps were taken by Lord Lytton with the help of his Finance Member, Sir John Strachey to strengthen the decentralisation of finance. More heads of expenditure were transferred to the provinces (Government of India 1877). But, instead of granting power to tax these subjects the provinces were given a share in the Central revenues. Certain heads of revenue, such as excise, stamps, law and justice fees, proceeds of the license tax and some minor railway receipts were allotted to the provincial governments. It was stipulated that the revenue from these sources was to be taken in part by the provincial governments. But if the provincial governments showed any surplus over an estimated figure, one half of the surplus should be given to the central government. In case of a deficit, the central government agreed to bear half the loss.

\section{c. Quinquennial Arrangement}

The 'Provincial Financial Settlements' under Mayo Scheme were subject to revision annually. But from 1882 they were made on quinquennial basis by Lord Ripon.

The quinquennial settlements substituted the 'assigned revenue' with the 'divided heads' or 'shared revenues'. It abolished the system of fixed annual grants from the centre to the provinces and introduced resource sharing between the central and provincial governments. The revenue heads were divided into 'Imperial Heads', 'Provincial Heads' and 'Divided Heads'. The centre retained revenue from the Imperial Heads and the provinces from the Provincial Heads. The revenue from the Divided Heads was distributed between them. Since the total revenue from Provincial Heads and Divided Heads were insufficient to meet the needs of the provincial governments, a share of land revenue was made available to them, together with fixed cash assignments. New settlements were made after the expiry of five years. However, at the end of fifth year the balances standing to the credit of provinces were taken over by the central government.

The Ripon Scheme is important for three major reasons. Firstly, steps were taken for the first time to divide the total resources of revenue under various heads. Secondly, instead of granting a fixed annual grant to the provinces, they were given a share in growing sources of revenue. Thirdly, the major source of the revenue, i.e., land revenue, was made as a divisible income. Perhaps the origin of resource sharing under different heads existing under the Constitution of India can be attributed to the Ripon Scheme. 
The 'Provincial Financial Settlements' were made in 1887, 1892, and 1897 without any change in principle. ${ }^{3}$ In the first and second settlements, the shares of the Provinces were reduced. ${ }^{4}$ However, the third revision in 1896-97 increased the share of the Provinces. In this settlement, an estimate was made on the expenditure on provincial services in each province, and an adequate proportion of provincial revenues were set aside. 'Provincial Financial Settlement' was viewed with contempt by many writers as the real purpose of it was mainly to salvage the Imperial finance from the crisis which it was facing for more than three and a half decades (Banerjea 1939, Chand 1930). ${ }^{5}$ According to K.T. Shah, "the governing principle in the thirty years of provincial finance, since its inauguration by Lord Mayo, had remained unaffected: administrative convenience- for the Government of India almost invariably" (Shah 1929). ${ }^{6}$

\section{d. Quasi -Permanent Settlements}

Lord Curzon drew up a scheme of quasi-permanent nature in 1904 to get rid of the defects existed under the quinquennial arrangement. The quasi -permanent settlement was on the foundation of three principles: (a) The provinces must be given a more permanent interest in their revenue and expenditure, (b) The ratio of the revenue assigned to the provinces to their expenditure should be approximately the same ratio of the central revenue to the central expenditure, and (c) The provincial assignment must include a slightly larger share of growing revenues. Under the quasi-permanent settlement, there were subjects exclusively allotted to the Government of India and the Provinces and certain revenues were shared between them. The Provincial Government also secured lump-sum grants from the

${ }^{3}$ The Imperial Government did not make the settlement in 1901-02 due to certain difficulties they were facing.

${ }^{4}$ In 1887, the Centre collected seventy five percent proceeds of revenue from divided heads and the Provinces were given only the balance twenty five percent.

${ }^{5}$ Banerjea stated that "the real motive of the scheme was to give relief to the Centre rather than to provide larger revenues to the Provinces" while Chand held that the "only consideration which really weighed with the Government of India was that of administrative convenience".

${ }^{6}$ Schah observed that the Government of India was the absolute master of the situation; they varied and re-formed the contracts at their discretion, or for their convenience. Neither borrowing on their own credit, nor additional or supplementary taxation on their own hook, was allowed to the Provinces, who therefore remained irretrievably tied to the apron strings of the Central Government. pp. 93-94. 
Central surpluses. In order to make up the gap between the provincial revenue and expenditure, a fixed cash assignment under the Land Revenue was assigned to them. With respect to famine relief, an arrangement was made by the Central Government to set aside some amount to meet any contingency. ${ }^{7}$

In 1908 the 'Royal Commission on Decentralisation' was appointed to investigate the whole issue of financial relations with special reference to expenditure control. Though the Commission expressed 'general satisfaction' with the existing financial relations between the Government of India and the Provincial Governments, it argued for a reorganization of the system (Royal Commission 1909).

The Government of India, by considering the reasoning of the Commission, made certain modifications in the fresh settlements of 1911-12. They sought to convert the fixed assignment into completely provincialised revenues from heads that were then divided. The settlement of 1911 wholly provincialised the forests revenue and expenditure. In respect of excise and land revenue, the allocation was variable among Provinces. ${ }^{8}$ Accordingly, cash assignments to the Provinces were reduced in proportion to the accretion in revenues from the above changes. Provincial claims for independent powers of borrowing and taxation were not accepted by the central government (Government of India 1912).

\section{e. Permanent Settlements}

The 'quasi- permanent settlement' was converted into 'Permanent Settlement' in 1912 by Lord Hardinge. Under this settlement the Government of India received the whole revenue under the heads of opium, salt, customs, tributes from native states, post office, telegraph, railways, mint and military receipts. It was responsible for the expenditure on the corresponding heads. Of the provincial revenue, about two third was derived from the three divided heads of land revenue, excise and assessed taxes. The system of grants was retained. The 'Permanent Settlement' remained in operation till 1918-19.

\footnotetext{
${ }^{7}$ It set aside every year a sum roughly equal to the famine liabilities of each province to the credit of that province, and utilizing that accumulated reserve when a famine occurred, without affecting its normal resources. If this did not suffice to meet the particular liability, the Imperial and the provincial government concerned must meet the excess equally.

${ }^{8}$ Excise entirely in Bombay, and to the extent of three quarter in the Central and the United Provinces; Land revenue - half in Punjab and five of eight in Burma.
} 
During this phase the Government of India continued to be constitutionally responsible for exercising the general executive supervision of the administration of the provinces, in the collection of revenues, and in the administration of services assigned to them. The provincial governments were not granted with any powers of independent taxation, and were not allowed to borrow even on their own credit in the open market. This arrangement was criticized by Shah (1929) in the following words: "The Provincial Governments, up to 1920, owed no responsibility to the people they governed. The Government of India were themselves an absolute and irresponsible bureaucracy; but they owed a shadow of responsibility to Parliament. They accordingly refused to concede any powers of independent taxation, direct or indirect, to the provinces, on political as well as financial grounds. And, lest provincial competition with the Government of India, committed to heavy projects of material development, requiring considerable annual borrowing, should prejudice the credit of the Central Government, they likewise declined to allow provinces to borrow on their own credit in the open market." The provincial budgets needed the approval of the Government of India. Even though some subjects of revenue and expenditure were granted to the Provinces there was no real fiscal autonomy to them. Under all settlements, the subjects also substantially remained same. There was a direct control by the central government over the fiscal governance of the provinces and they had to depend heavily on the central grants to meet their ordinary administrative expenses.

\section{Period of formal decentralization: 1919 to 1935}

In the history of fiscal federalism in India, the period from 1919 to 1935 is remarkable for the considerable change in the approaches of the Government of India in respect of the devolution of resources to the provincial governments. Several Committees and Commissions were appointed to look into the matter of financial decentralisation and their recommendations helped to develop a decentralised financial administration in India. To begin with, the MontagueChelmsford Report on Constitutional Reforms was submitted in 1918, which led to the passing of the Government of India Act, 1919. It was followed by Indian Statutory Commission, 1930, First Peel Committee, 1931, White Paper on Indian Constitutional Reforms, 1931, Percy Committee, 1932, Second Peel Committee, 1932, and Parliamentary Committee, 1934. Role of these committees and commissions in developing a formal decentralisation of finance in India are briefly given below. 
a. Montague-Chelmsford Report on Constitutional Reforms and the Government of India Act, 1919

Lord Chelmsford was appointed as the Governor General of India in 1916 and soon after his arrival he declared that "the endowment of British India as an integral part of the British Empire with self- government was the goal of British rule" (Banerjee 1949).To achieve these goals, he was of the opinion that the Constitution of India required major and radical reforms. E.S. Montague, the then Secretary of State, came to India in 1917 on an invitation made by the Governor General to study and report about the necessary constitutional reforms in India. The MontagueChelmsford Report on Constitutional Reforms was submitted in 1918.

The Mont-Ford Report expressed strong disapproval against the existing financial relations between the Centre and the provinces for the control and interference of the Central Government in provincial matters. ${ }^{9}$ An important proposal of the Report was to dispense with the system of 'divided heads' and to allot the residual power of taxation to the Provinces (Montague\& Chelmsford 1918). ${ }^{10}$ The Provincial subjects were divided into "Reserved" and "Transferred" and the Governor in Council controlled the "Reserved Subjects" while the Governor acting with the Ministers controlled the Transferred Subjects". "11 Finance, land revenue, famine relief, irrigation and waterways, mines, electricity etc., were included in the reserved subjects while the transferred subjects included local self government, education, public works, and excise. $^{12}$ The sources of revenue of the provinces included the receipts from provincial subjects, a share in the income- tax and taxes on specific items.

${ }^{9}$ The Report made a major change in the approach on the basis that provincial autonomy could be achieved only if the Provinces were made independent of the Union for the means of provincial development and consequently the report made certain serious searches for a new basis of division of financial resources between the Centre and the Provinces.

${ }^{10}$ It proposed that "an idea should first be made of the scale of expenditure required for the upkeep and development of the services which clearly appertain to the Indian sphere; that resources with which to meet this expenditure should be secured to the Indian Government; and that all other revenues should then be handed over to the Provincial Governments, which will thenceforth be held wholly responsible for the development of all provincial services." (§ 209)

11 The Executive Government of a Province consisted of two parts: one comprising the Governor and his Executive Council, and the other consisting of the Governor acting with his Ministers.

12 This system of dyarchy did not work well due to political and administrative reasons and the Government was forced to replace it with a responsible unitary government in each province under the Government of India Act, 1935. 
The Report also provided for a complete separation of central and provincial budgets, which were until then interlinked and the Central Government could make use of any surplus in the provincial exchequer (Montague\& Chelmsford 1918). ${ }^{13}$ With regard to provincial taxation, the report recommended for limited powers to the provinces. ${ }^{14}$ In respect of provincial borrowings, the Report recommended that the provinces' power of borrowing should be exercised only with the previous sanction of the Government of India even if such borrowings were to be effected locally. ${ }^{15}$ Since the 'divided heads' had been proposed to be abolished and resources rearranged, it was calculated that the provinces would have a surplus and the Government of India would have a deficit. This deficit was proposed to be made good by fixed contributions by the provinces, which would form the first charge upon the provincial revenues. ${ }^{16}$ To advise on the amounts of provincial contributions the 'Financial Relations Committee' was appointed under the chairmanship of Lord Meston. ${ }^{17}$

The Meston Committee suggested that the basis of provincial contribution should not be the estimated budgetary surplus of the provinces but should be the increased spending power of the provinces. It recommended that the standard contributions should be computed on the basis of the relative taxable capacity of the provinces and other economic factors. Provincial contributions under the Meston Settlement during the 1920s provided perhaps the only example of transfer of funds from the provinces to the centre in the long history of fiscal federalism in India (Sury 1992).

The Government of India Bill based on the Mont-Ford Report was introduced in the House of Commons and it became an Act on December 23, 1919, and came into full operation on the first day of January 1921. The Government of India Act, 1919 marked the beginning of formal decentralisation of finances in India. It abolished the system of 'divided heads' of revenue and provided for separate heads of revenue both for the centre and the provinces. Conferring the right of taxation and power of borrowing on the provinces was a milestone in the evolution of federal finances. The

\footnotetext{
${ }_{14}^{13} \S 208$

14 Requirement of the previous sanction of the Government of India and the Governor General's power of veto made this recommendation meaningless $(\S 210)$.

15 \$ 211

1687 percent of gross provincial surplus was proposed to be contributed to the central Government.

17 The Committee was to advice on: (a) the contributions by various provinces for the year 1921-22; (b) modifications to be made in the provincial contributions; (c) future financing of the provincial loan account; and (d) share of income tax to the Government of Bombay.
} 
Act divided the subjects of legislations into two; 'Central' and 'Provincial'. ${ }^{18}$ The subjects of legislations were given in two schedules. With regard to the subjects listed in schedule I the provinces could levy taxes without the previous sanction of the Governor-General. ${ }^{19}$ On the subjects of schedule II, the provinces could permit local bodies to levy tax, without prior sanction of the Governor-General. However, the Governor-General-in-Council had power to add any new tax to either schedule.

\section{b. Indian Statutory Commission, 1930}

In November 1927, Parliament appointed the Indian Statutory Commission under the Chairmanship of Sir John Simon to enquire into the working of the system of Government of India Act, 1919. Report of the Commission was published on May 27, 1930.

The Commission recommended the abolition of diarchy in the provinces and the establishment of unitary administration by doing away with the classification of subjects into "reserved" and "transferred". It did not favor the system of grants-in-aid as it involved some measure of control which ran counter to the whole trend of constitutional development embodied in the recommendations of the Commission. Instead, it proposed for the creation of a provincial fund. This fund was to "be fed by products of taxes, voted by the Federal Assembly representing provincial units, but collected centrally" (Government of India, 1930).

Financial Advisor to the Commission, Sir Walter Layton made recommendations with regard to the division of resources between the centre and the provinces, which

18 The Central subjects included military, naval and aerial matters, foreign relations and relations with native states, railways, communications of military importance, post and telegraphs, currency and coinage, public debt, sources of imperial revenue, criminal and civil law and procedure, ecclesiastical administration and All-India services, central institutions of Scientific and Industrial research and all other matters not specifically declared as provincial subjects. The Provincial subjects included local self government, education, medical administration, sanitation and public health, public works, agriculture, development of industries, excise, civil veterinary department, fisheries, co-operative societies, famine relief, land revenue administration, irrigation, forests, administration of justice, police, prisons, inspection of factories, labour questions, provincial borrowings and agency functions.

19 The taxes mentioned in Schedule I were: (a) tax on land put to uses other than agricultural, (b) tax on succession, (c) tax on any form of betting or gambling permitted by law, (d) tax on advertisement, (c) tax on amusements, (f) stamp duty, (g) registration fee, and (h) stamp duties other than duties of which the amount was fixed by the Indian Legislation. 
were accepted by the commission. He recommended for a re-allocation of resources between the central and the provincial Governments, and suggested imposition of a number of new taxes. According to his recommendations, the total tax revenue should be categorised into four such as (i) Taxes collected and spent by the centre; (ii) Taxes collected and spent by the provinces; (iii) Taxes collected by the centre and distributed among the provinces on the basis of origin; and (iv) Taxes collected by the centre and distributed among the provinces on the basis of population.

The recommendations of the Indian Statutory Commission were considered in connection with the proposals for constitutional changes, which were discussed at the Round Table Conferences in London.

\section{c. First Peel Committee, 1931}

In the Second Round Table Conference ${ }^{20}$ a committee with Lord Peel as the chairman was appointed to investigate into the fiscal relations between the central and the provincial Governments and make necessary suggestions. ${ }^{21}$ The main recommendations of the First Peel Committee were: (i) Income Tax should be levied and collected by the central Government, but the entire proceeds of it should be assigned to the provinces; (ii) Central tax revenues should be mostly derived from indirect taxation; (iii) Any resultant central deficit should be met from provincial contributions which should not continue beyond fifteen years; (iv) If after fifteen years there was any surplus in the central finances, the central government should allocate the surplus to the units instead of reducing taxation; (v) Constitution itself should lay down the proportions in which such funds should be divided among the units; and (vi) an expert committee should be appointed to lay down the criteria by which the proceeds of income tax should be allocated among the provinces.

\section{d. Percy Committee, 1932}

As recommended by the First Peel Committee, an expert committee under the chairmanship of Lord Percy was appointed. The Committee rejected the existing system of distribution based on "origin", "population" and "collection" for not being

\footnotetext{
${ }^{20}$ Commenced on September 1, 1931.

${ }^{21}$ Also known as the First Peel Committee.
} 
equitable. ${ }^{22}$ The principal recommendations of the Percy Committee were (i) Income Tax should be shared between the centre and the provinces; (ii) The provinces should get a share of the proceeds of personal income tax of local incidences, personal super tax on the basis of collection from their residents, and a share of the tax on non-residents and undistributed profits of companies on the basis of population; (iii) Share of the provinces should be fixed for a period, subject to a revision in every five years; (iv) The central government should have power to levy surcharge on any tax levied and collected by it; and (v) Central grants should be distributed to the provinces on the basis of population.

\section{e. White Paper on Indian Constitutional Reforms, 1931}

The British Government in December 1931 issued a White Paper containing proposals for the Indian constitutional reforms which also contained certain financial proposals. The main financial proposals contained in the White Paper were (i) An amount not less than 50 per cent and not more than 75 per cent of the net proceeds of tax on income other than agricultural income should be assigned to the provinces on a prescribed basis; (ii) Central and provincial governments should have power to levy surcharges on income tax for their individual purposes; (iii) Proceeds of agricultural income tax and corporation tax should go to the provincial and the central government respectively; (iv) Central government should grant to the provinces the whole or a part of the proceeds of salt duty, excise duty on commodities included in Central List and export duties; and (v) Terminal taxes and death duties should be levied and collected by the central government but the proceeds of which should be distributed among the provinces.

\section{f. Second Peel Committee, 1932}

The Reports of the Peel Committee and Percy Committee and proposals in the White Paper were considered by the Federal Structure Committee and decided that the distribution of subjects of taxation and devolution of finances should be

22 The Committee was of the opinion that the allocation based on 'origin' was theoretically commendable but would result into arbitrariness. Distribution based on 'population' was not fully scientific but could be adopted in certain circumstances and the criteria of 'collection' would be prejudicial to some Provinces. 
considered afresh. A Sub-Committee was constituted for this purpose andwas headed by Lord Peel. However, the second Peel Committee merely endorsed the recommendations of the Percy Committee without making any significant suggestions.

\section{g. Parliamentary Committee, 1934}

In 1933-34, the Joint Parliamentary Committee on the Indian Constitutional Reforms examined the question of allocation and devolution of resources. The Committee generally agreed with the proposals made in the White Paper and suggested that the provincial share of income tax should be prescribed by an Order-in-Council and the share of the provinces should not exceed half of the net revenue from income tax. It further recommended that the provinces should be prevented from imposing surcharges on personal income tax.

Government of India Act, 1919 marked the beginning of a formal decentralisation of finance between the centre and the provinces. Strict control of the centre over the provincial finances was, to some degree, avoided and autonomy to a limited extent was given to the provincial governments. Although, under the Government of India Act, 1919 fiscal powers were demarcated between the centre and the provinces and the possibilities of overlapping were minimised, the central government was vested with overriding powers. The fundamental issue was that the fiscal powers of the provinces were not derived from a sovereign constitution but were delegated by the supreme central government. Such a system could not be considered as a federal system. But, that is not a reason to undermine the contribution made by the Government of India Act, 1919 for setting up a federal system in the long run. The role of the Government of India Act, 1919 is that it formalised the financial relations between the central and the provincial governments, which accelerated the process of establishing a constitutional fiscal federalism.

\section{Decentralisation to federal finances: 1935 to 1947}

The Government of India Act, 1935 was passed into law and received the Royal assent on August 4, 1935 and came into force on April 1, 1937. ${ }^{23}$ Although the

${ }^{23}$ Except Part II (Federation) and Part II (Federal Railway Authority) 
political leadership did not accept (Sikri 1979) ${ }^{24}$, it marked the turning point in the evolution of federal financial relation. It provided the framework for the Centreprovince financial relations as incorporated in the present Constitution of India (Basu 1987). ${ }^{25}$ For the purpose of demarcation and distribution of legislative powers between the central and provincial Governments, three Lists were provided in the Seventh Schedule to the Act. Central government and provincial governments had exclusive power to legislate upon the subjects enumerated under List I and List II respectively. In the case of subjects contained in List III, both the levels of government could legislate with dominance to central legislation over the provincial legislation in case of conflict. ${ }^{26}$ Lists I and II contained subjects of taxation whereas List III contained hardly any subject of tax.

The Government of India Act, 1935 did not bring any major change in the distribution of subjects between the centre and the provinces. It only reiterated the earlier principle of dividing the subjects between centre and provinces giving prominence to the former. The scheme of distribution of resources between the central and provincial governments under the Act could be classified into five as follows:

a. Taxes levied, collected and retained by the central government

b. Taxes levied, collected and retained by the provincial governments

c. Taxes levied and collected by the central government but assigned to the provinces

d. Taxes levied and collected by the central government but shared with the provinces

\section{e. Grants-in-aid}

The provinces could borrow in the open market on the security of their revenues. Prior sanction of Government of India was necessary if a province wanted to float a loan outside India or owed any debt to, or guaranteed by, the Government of India.

${ }^{24}$ Nehru condemned it as legislation "not worth the paper on which it had been printed" and Jinnah denounced it as "fundamentally bad, thoroughly rotten and entirely unacceptable."

25 "While under all the previous Government of India Acts, the Government of India was unitary, the Act of 1935 prescribed a federation, taking the Provinces and the Indian States as Units".

${ }^{26}$ The Indian Constitution, 1950 also follows the same pattern in the case of legislative powers of the Union and the State Governments. 
A significant difference from the earlier Acts was that under the Government of India Act, 1935, the revenues and accounts of the provincial governments were detached from the Government of India. The provinces were responsible for their ways and means position and they could frame their own budgets

The Government of India Act, 1935 provided the basic structure of Indian fiscal federalism. Clarity was brought about the subjects of revenue and expenditure of both Central and Provincial Governments. Overlapping of revenue heads was minimised. A system was prescribed for the devolution of resources from the centre to the provinces in which budgetary deficits of the provinces were taken care of. But looking at the functional side, distribution of legislative subjects between the governments was unitary and those with more elasticity and buoyancy were granted to the centre. On the other hand, all major subjects that had a direct impact upon the lives of the people and development of the society were assigned to the provinces. The revenue was not commensurate with the expenditure if the provinces were taking up development programmes. There was a huge gap in the finances of the provinces and the grants-in-aid were not sufficient to make up this difference. This paradox prevented the provinces from implementing developmental projects and they were forced to concentrate mainly on ordinary administration.

\section{Starting of constitutional fiscal federalism: 1947 to 1950}

The Constituent Assembly was constituted in 1946 for drafting the Constitution for India. It did not make any serious attempt to reorganise the legislative subjects but preferred to follow the pattern developed by the Government of India Act, 1935. The provisions in the Draft Constitution relating to financial relations between centre and provinces were referred to an Expert Committee. Important recommendations of the Expert Committee were:

a. Net proceeds of Income Tax, including Corporation tax, should be shared between the centre and the provinces in the ratio of 40:60.

b. Sharing of the net proceeds of Jute Export Duty with the provinces should be dispensed with.

c. For balancing the revenue structure of the provincial governments, some share of central excise duties should be given to them. 
d. A Finance Commission should be constituted to deal with the matters connected with the distribution of revenue between the centre and the provinces and the provinces inter se.

Recommendations of the Expert Committee were accepted by the Constituent Assembly with minor modifications and they were incorporated in the draft Constitution. For the distribution of fiscal powers between the central and the provincial governments, the provisions of the Government of India Act, 1935 were more or less adopted. The Indian States Finance Enquiry Committee was set up in October 1948 under the chairmanship of V.T. Krishnamachari for achieving financial integration of the Part ' $B$ ' States and agreements were entered into between the Government of India and Part 'B' States (formerly called Princely States).

The Government of India (Distribution of Revenues) Order 1948 was effective only up to 31 March 1949. Since a Finance Commission could not be appointed immediately after the commencement of the Constitution, arrangements were to be made for the distribution of income tax and payment of grants-in-aid during the interim period. For the period between the commencement of the Constitution and the appointment of a Finance Commission, the above areas were regulated by the Order of the President. The arrangements for the allocation of income tax and jute export duty made by the Government of India immediately after the partition of the country caused dissatisfaction among the provinces. In December 1949, these matters were referred to C.D. Deshmukh to formulate principles for the devolution of income tax among Part A States (formerly British Indian provinces). The Deshmukh Award came into operation on 1 April 1950 and remained in force until31 March 1952. ${ }^{27}$

The First Finance Commission of India was constituted under Article280 of the Constitution of India by a Presidential Order dated 22 November 1951, under the chairmanship of K.C. Neogy.

27 There was no comprehensive scheme of redistribution under the Deshmukh award. It only recommended for a reallocation of the sums released on partition. Accordingly, there was no change in the percentage share of Assam, Bombay and Orissa; reduced the shares of Madras by 0 .5 percent, of U.P. by 1 percent and of Bihar by 0.5 percent; augmented the share of West Bengal by 1.5 percent, of Punjab by 0.5 percent. West Bengal was granted Rs. 105 lakhs, Assam Rs. 40 lakhs, Bihar Rs. 35 lakhs and Orissa Rs. 5 lakhs in lieu of Jute and Jute Goods Export Duty. 


\section{Conclusion}

It can be seen that the Fiscal Federalism under Indian Constitution is a result of historical evolution spreading for almost a century. Over the time, a too rigid unitary system with immense scope of discretionary power to the Central Government was transformed into a constitutionally regulated federal system. Through various commissions, committees and parliamentary enactments this was achieved. While drafting a new Constitution for the Indian Republic, the framers preferred to preserve the provisions of the Government of India Act, 1935 with slight modifications in the field of financial relations between the centre and the provinces. As the Government of India Act, 1935 was unique for its strong centripetal tendencies the same were reflected in the new Constitution as well. 


\section{References}

[1] Banerjea, P. 1939, Provincial Finances in India, MacMillan\& Co. Ltd., London.

[2] Banerjee, A.C. (Ed.) 1949, Indian Constitutional Documents 1757-1939, Vol. III, Mukherjee \&Co. Culcutta.

[3] Basu, D.D. 1987 Introduction to the Constitution of India, Prentice Hall of India Pvt. Ltd., New Delhi.

[4] Chand, G. 1930, The Essentials of Federal Finance: A Contribution to the Problem of Financial Re-adjustment in India, Humphrey Milford, Oxford University Press, London.

[5] Government of India 1867, Legislative Council Proceedings, Finance Statement, 1867-68

[6] Government of India 1877, Resolution, Financial Department, No. 1709 of $22^{\text {nd }}$ March, 1877.

[7] Government of India 1912,Resolution on Provincial Finance No. 27-F dated $18^{\text {th }}$ May 1912

[8] Government of India 1930, Report of the Indian Statutory Commission

[9] Jather, G.B. and Beri, S.G. 1932, IndianEconomics,Vol. II,Humphrey Millford, Oxford University Press, London.

[10] Kale, V.G. 1917, Indian Administration, Aryabhushan Press, Poona.

[11] Montague-Chelmsford Report on Indian Constitutional Reforms, 1918.

[12] Report of the Royal Commission of Decentralisation, 1909.

[13] Shah, K.T. 1929,Federal Finance in India,D.B. Taraporevala\& Sons, Bombay.

[14] Sikri, S.L. 1979,A Constitutional History of India,S. Nagi\& Co., Jullundhar.

[15] Sury, M.M. 1992, "Centre-State financial Relations in India: 1870-1990", Journal of Indian School of Political Economy, Vol.4, No.1. 